\title{
Spanish scholarly journals in WoS and Scopus: The impact of open access
}

\author{
Ernest Abadal \\ Universitat de Barcelona \\ abadal@ub.edu \\ Remedios Melero \\ IATA, CSIC \\ rmelero@iata.csic.es \\ Rosângela Rodrigues \\ Universidade Federal de Santa Catarina, Brazil \\ rosangela.rodriguesufsc@gmail.com \\ Miguel Navas-Fernández \\ Universitat de Barcelona \\ miguel.navas@ub.edu
}

\begin{abstract}
The aim of this study was to determine the impact of open access on the publishing policies of Spanish scholarly journals indexed by WoS and Scopus. The study sample was obtained in October 2013. After discarding those that were not published in Spain and those that were inactive, we were left with a total of 406 journals (392 in Scopus and 171 in WOS, with an overlap of 157). A set of seven key indicators was established: age, subject area, language, publisher, portals, type of access and copyright. Most of the data were gathered by directly analyzing the websites of the journals and information from the Dulcinea directory was also used. Most of the journals (63\% of the total) were first published after 1980. Universities and commercial publishers were the most significant publishers, accounting for $42 \%$ and $31 \%$ of all journals, respectively. Social sciences and health sciences were the most significant disciplines, accounting for $33 \%$ each. Of the journals, $60 \%$ were available free immediately after publication and $76 \%$ granted permission for self-archiving a version of the manuscript. By combining the two results, we estimated that $48 \%$ of all journals were open access (offering free access and permission for selfarchiving).
\end{abstract}


Keywords: scholarly journals, Spain, open access, self-archiving, licenses, WoS, Scopus

\section{Introduction}

The situation of scholarly journals varies considerably between countries. Journals in the USA, the Netherlands, Great Britain and Germany-the nerve centers of scientific communication, together accounting for $75 \%$ of the journals indexed in the Web of Knowledge-differ greatly from those in countries on the periphery of science. Several descriptive studies have been made on the situation of scholarly journals in these peripheral countries ${ }^{1}$. We will review the literature on some of them: the Nordic countries and Croatia in Europe, Brazil and Mexico in Latin America, and China and India in Asia.

In the Nordic countries ${ }^{2}$ commercial publishers are predominant, except in Finland, where societies and associations are predominant. The social sciences and humanities journals are usually published in local languages, while science, technology and medicine journals are mainly in English. Finally, the number of open access journals is fairly low. In Croatia ${ }^{3}$, non-profit publishers are predominant (44\% are universities, $28 \%$ are professional associations and $26 \%$ are scientific institutions) and social sciences and humanities are the main disciplines (58\%). The language of publication is Croat in $40 \%$ of the journals (mainly in social and human sciences), English in 30\% (mainly in science and technology), and Croat and English (bilingual) in $29 \%$. English is therefore present in $59 \%$ of the journals.

In Brazil, Packer ${ }^{4}$ found an increase in the number of journals in WoS (from 19 in 2005 to 71 in 2009), largely thanks to the role played by SciELO. According to a study by Rodrigues and Abadal ${ }^{5}$, universities (47\%) and scientific associations $(40 \%)$ are the main publishers and open access is widespread, having been adopted by $97 \%$ of the journals. In Mexico, Sánchez-Herández et al. ${ }^{6}$ conducted a study based on 102 journal titles contained in Latindex. The social sciences and humanities accounted for $54 \%$ of the journal titles. The publishing institutions were mainly universities and research centers, and commercial publishers were not mentioned.

China has a large number of journals. Xiao-Jun ${ }^{7}$ stated that there were 4936 journals in 2010 according to government sources, although according to the Chinese Institute of Scientific and Technical Information the figure was 6400 . Only 5\% of journals in social and human sciences are open access ${ }^{8}$. Sun and $\mathrm{Mao}^{9}$ noted the 
emergence of a new scientific publication system that, unlike the previous one, includes private financing and profit and is accelerating and facilitating the progress of Chinese industry in this sector. In India Mukherjee ${ }^{10}$ found a considerable increase in journals in the period 2003-2012. In terms of subject areas, $90.28 \%$ were natural sciences and technology, leaving only $9.78 \%$ in social sciences and arts. Article processing charges (APCs) of $\$ 10$ to $\$ 400$ were applied by $43 \%$ of the journals and almost all the open access journals were in DOAJ.

The first descriptive studies of scholarly journals in Spain were few in number and date back to just over ten years ago. Carmen Urdín ${ }^{11}$ presented a description of the sector based on the data of 2223 scholarly journals included in the CINDOC directory of journals and analyzed the distribution of journal titles by subject area (humanities and social sciences accounted for $60 \%$ of the total), type of publisher (commercial publishers accounted for $28 \%$, followed closely by universities with $27 \%$ ), place of publication (Madrid was in the lead with $39 \%$ ) and format (only $4 \%$ had a digital full text version).

Soon after, María Bordons ${ }^{12}$ analyzed the 30 Spanish journals that were included in the Journal Citation Reports (JCR) in 2000, focusing on the type of publisher, international scope (through the composition of the editorial boards), impact and citation habits (self-citation, etc.). At that time medical journals were predominant (60\% of the total) and commercial publishers accounted for $40 \%$ of the total (60\% in medicine). Another study ${ }^{13}$ based on 3000 journals (from a variety of directories) analyzed aspects not dealt with by Urdín (particularly domestic and international dissemination and visibility). Of these journals 57\% had been created since 1990 and almost three quarters specialized in social and human sciences; they were written primarily in Spanish, with a few in English. The total number of journals reported in this study was high because it included inactive journals.

The literature also includes studies on Spanish journals that do not include specific data but rather propose courses of action to improve the dissemination and impact of university journals ${ }^{14}$ or analyze the weaknesses of Spanish journals in the humanities and social sciences ${ }^{15}$ suggesting mergers and joint publication of journals as possible strategies.

As can be seen in this initial literature review, so far there have been no up-to-date descriptive studies of Spanish scholarly journals like those found in other countries or in other areas of the media (press, radio, television, etc.). This absence led us to collect data on the sector and to study the situation of the Spanish journals indexed by WoS and Scopus, which form a compact, high-quality and representative sample of the total. 
The aim of this study was therefore to analyze the current situation of Spanish scholarly journals indexed by WoS and Scopus in order to determine the impact of open access on their publishing policies. We consider, first, a set of basic descriptive features (age, subject area, publisher, language and presence on portals) and, second, the impact of open access on these journals, taking into account the type of access and permission to self-archive the published works.

\section{Material and methods}

The quality of Spanish scholarly journals has improved over the last 10 years, resulting in greater visibility and external recognition. This recognition is apparent in the increase in the number of journal titles indexed in the two main international indexes, Web of Science (ThomsonReuters) and Scopus (Elsevier). For example, in the period 2005-2010 the number of Spanish journals in JCR rose from 54 to $116^{16}$.

We analyzed the journals included in Web of Science and Scopus in October 2013, which totaled 443 titles (171 in WoS and 392 in Scopus). The results were then filtered to exclude journals that were not published in Spain or were inactive. The resulting total of 406 journal titles was the sample on which the study was carried out.

It is also important to place this figure in relation to the total of Spanish scholarly journals, albeit approximately. If we query the four major directories we find a diversity of figures, ranging from 1600-1800 journal titles in Dulcinea and Latindex to nearly 2500 in Cindoc and Ulrich's. Dulcinea and Latindex update their data more frequently and, in our opinion, contain more reliable data. It can therefore be concluded that a little over $20 \%$ of Spanish scholarly journals (about 400 out of a total of about 1800) are listed in quality indexes.

Table 1. Active Spanish scholarly journals

\begin{tabular}{lc} 
Directory & Journal titles \\
\hline Cindoc & 2488 \\
Dulcinea & 1619 \\
Latindex & 1791 \\
Ulrich's & 2468
\end{tabular}

For each journal we collected information on seven indicators: age, subject area, publisher, language, portals hosting them, type of access and copyright. Most of the 
data were collected by directly analyzing the websites of the journals and even performing checks on published issues (to determine the language, for example). Information on the type of access and permission for self-archiving were taken from the Dulcinea database, which is based on direct analysis of the websites of the journals and the information provided by the publishers. We were thus able to obtain more reliable and up-to-date information than that available in WoS and Scopus.

\section{Results}

\subsection{Data of first issue}

The scholarly journals analyzed were very recent: 95 (23\%) were less than 12 years old, although 6 (1.5\%) predated 1914.

Figure 1. Evolution of number of journals by year of publication

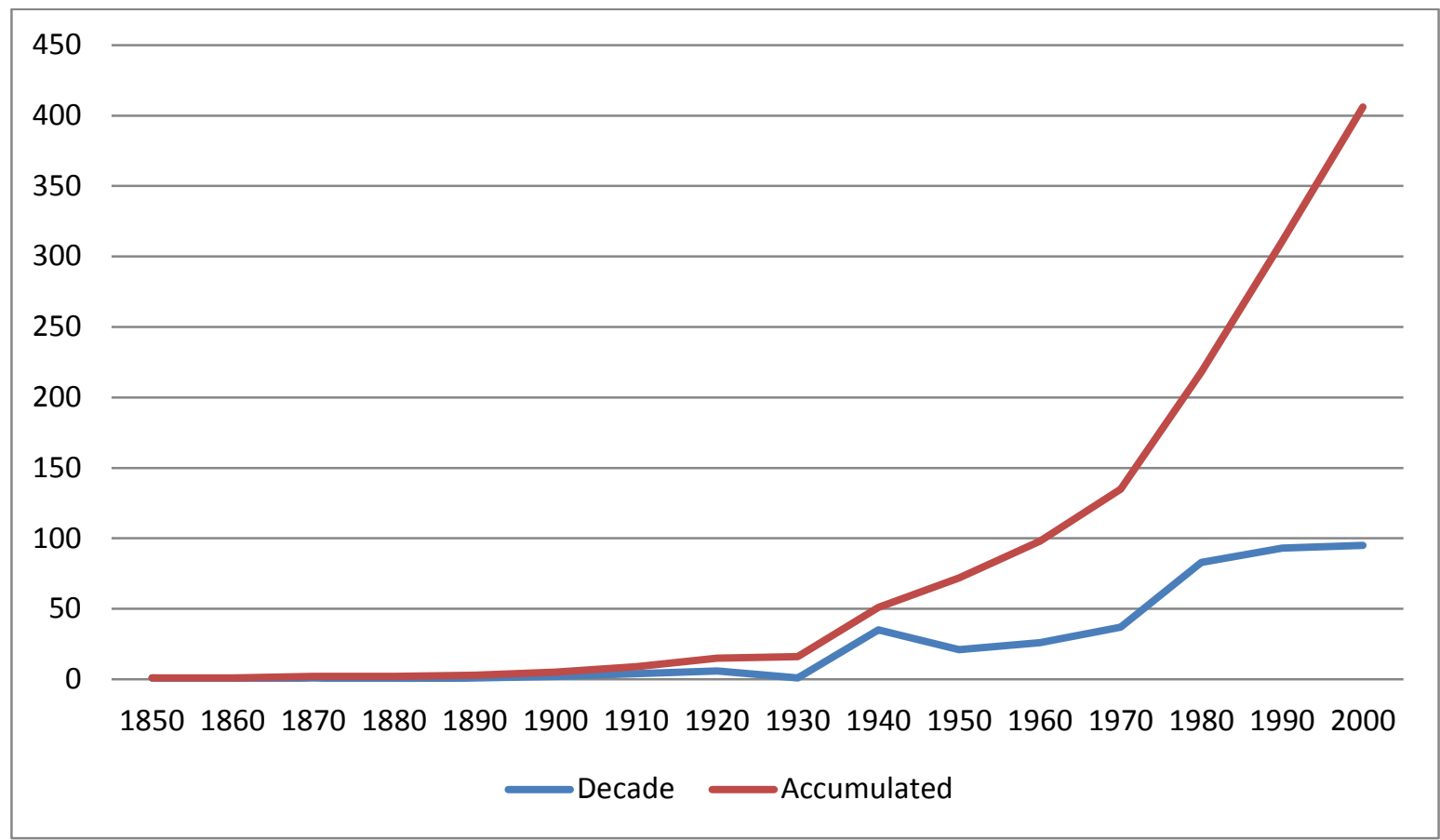

NB: The 2000s are extended to 2012.

The greatest growth in the number of journal titles occurred in the last three decades, when two-thirds of the titles appeared: $20 \%$ in the 1980 s, $23 \%$ in the 1990 s and $23 \%$ in the 2000s. 


\subsection{Subject areas}

For the thematic classification of the journals, Scopus uses 30 subject areas and WoS uses over 100. Although the use of these descriptors would allow for a very detailed study, we felt it would be more revealing to use a model with a smaller number of categories. We therefore standardized the subjects from the two indexes to fit the seven categories listed in Table 2.

Table 2. Distribution by subject area

\begin{tabular}{|c|c|c|}
\hline Subject area & Journals & $\%$ \\
\hline Arts and humanities & 70 & $17.2 \%$ \\
\hline Health sciences & 135 & $33.3 \%$ \\
\hline Life sciences & 24 & $5.9 \%$ \\
\hline Experimental sciences & 13 & $3.2 \%$ \\
\hline Social sciences & 132 & $32.5 \%$ \\
\hline Engineering & 20 & $4.9 \%$ \\
\hline Mathematics and physics & 12 & $3.0 \%$ \\
\hline Total & 406 & $100.0 \%$ \\
\hline
\end{tabular}

The most noteworthy finding was the predominance of health sciences and social sciences, each with a third of the total, followed at considerable distance by the arts and humanities. Except for health sciences, these are disciplines in which the authors tend to publish in journals of their own geographical area. The remaining four fields (experimental sciences, life sciences, engineering, mathematics and physics) had a much smaller presence (between 3\% and 6\%) because these subjects are highly internationalized (Spanish authors publish in foreign journals). In the study by Bordons ${ }^{17}$, health sciences represented $60 \%$ of the total, double the present figure.

\subsection{Publishers}

We established four types of publisher based on who publishes the journal regardless of who its owner or holder is. For example, journals belonging to a scientific society or university may be produced and distributed by a private publisher such as Elsevier or Springer. 
a) Private non-profit organizations: these include professional associations, scientific societies, royal academies and foundations.

b) Commercial organizations: publishing companies.

c) Government agencies: these include all organizations that depend on the public administration (excluding universities and research centers).

d) Academic institutions: universities and research centers such as the Spanish National Research Council (CSIC).

As shown in Table 3, the predominant types of publisher were universities and research centers (41\%), followed by commercial publishers (31\%). At the opposite extreme are government agencies, which represent only $5 \%$. In the study by Bordons $^{18}$, commercial publishers were the predominant type, with $40 \%$ of the total.

Table 3. Publishers and subject areas

\begin{tabular}{|c|c|c|c|c|c|c|c|c|c|}
\hline \multirow[b]{2}{*}{ Subject } & \multicolumn{2}{|c|}{$\begin{array}{l}\text { Private non- } \\
\text { profit }\end{array}$} & \multicolumn{2}{|c|}{ Commercial } & \multicolumn{2}{|c|}{ Government } & \multicolumn{2}{|c|}{ Academic } & \multirow[t]{2}{*}{ Total } \\
\hline & No & $\%$ & No & $\%$ & No & $\%$ & No & $\%$ & \\
\hline Arts and humanities & 11 & $15.7 \%$ & 5 & $7.1 \%$ & 2 & $2.9 \%$ & 52 & $74.3 \%$ & 70 \\
\hline Health sciences & 28 & $20.7 \%$ & 99 & $73.3 \%$ & 2 & $1.5 \%$ & 6 & $4.4 \%$ & 135 \\
\hline Life sciences & 7 & $29.2 \%$ & 1 & $4.2 \%$ & 4 & $16.7 \%$ & 12 & $50.0 \%$ & 24 \\
\hline Experimental sciences & 4 & $30.8 \%$ & 0 & $0.0 \%$ & 2 & $15.4 \%$ & 7 & $53.8 \%$ & 13 \\
\hline Social sciences & 32 & $24.2 \%$ & 12 & $9.1 \%$ & 9 & $6.8 \%$ & 79 & $59.8 \%$ & 132 \\
\hline Engineering & 7 & $35.0 \%$ & 3 & $15.0 \%$ & 0 & $0.0 \%$ & 10 & $50.0 \%$ & 20 \\
\hline Mathematics and physics & 2 & $16.7 \%$ & 6 & $50.0 \%$ & 1 & $8.3 \%$ & $\begin{array}{r}3 \\
16\end{array}$ & $25.0 \%$ & 12 \\
\hline Total & 91 & $22.4 \%$ & 126 & $31.0 \%$ & 20 & $4.9 \%$ & 9 & $41.6 \%$ & 406 \\
\hline
\end{tabular}

By subject area, the commercial publishers had a greater presence in health sciences (73\%), followed by mathematics and physics (50\%). Elea GiménezToledo ${ }^{19}$ reports that several Spanish scholarly journals have reached agreements with Elsevier, especially in the area of health, in order to obtain a brand image and wider dissemination and visibility. Furthermore, in 2005 Elsevier acquired the publisher Doyma, which formerly published many of the Spanish medical journals. The universities had a greater presence in Arts and Humanities (74\%).

Table 4 shows the 16 major publishers with at least four journals, which held $54 \%$ of the journal titles, whereas 173 publishers shared the remaining 46\%. The first three places corresponded to a commercial publisher, a research center and a university. Elsevier was prominent in first place (18\%) thanks to its takeovers and its service provision in recent years, especially in health sciences. It was followed by the CSIC 
(9\%) and the Universidad Complutense de Madrid (7\%), two public institutions that have considerably improved the quality of their journals and achieved good results, as evidenced by our study. University presses had a significant presence in the leading group (10 out of 16).

Table 4. Major publishers

\begin{tabular}{lrr} 
Publisher & Journals & $\%$ \\
\hline Elsevier & 74 & $18.2 \%$ \\
Consejo Superior de Investigaciones Científicas (CSIC) & 36 & $8.9 \%$ \\
Universidad Complutense de Madrid & 27 & $6.7 \%$ \\
Springer & 11 & $2.7 \%$ \\
Universitat Autònoma de Barcelona & 9 & $2.2 \%$ \\
Universitat de Barcelona & 9 & $2.2 \%$ \\
Universidad de Navarra & 8 & $2.0 \%$ \\
Universidad de Murcia & 6 & $1.5 \%$ \\
Universidad de Granada & 6 & $1.5 \%$ \\
Universidad del País Vasco & 6 & $1.5 \%$ \\
Centro de Estudios Políticos Constitucionales & 5 & $1.2 \%$ \\
Fundación Infancia y Aprendizaje & 5 & $1.2 \%$ \\
Permanyer & 4 & $1.0 \%$ \\
Universidad de Oviedo & 4 & $1.0 \%$ \\
Universidade de Santiago de Compostela & 4 & $1.0 \%$ \\
Universidade de Vigo & 4 & $1.0 \%$ \\
& $\mathbf{2 3 6}$ & $\mathbf{5 4 \%}$
\end{tabular}

\subsection{Language}

Although all the journals analyzed have browser interfaces and abstracts in two or three languages, this section only takes into account the language of the articles published. To determine this we directly reviewed the full text of articles published in two random issues of each journal between 2012 and 2013.

We considered only the main languages that appeared regularly in each issue. Secondary ones that appeared sporadically were not taken into account in classifying the journals into one of the following languages: Spanish, English, Catalan, Italian, Spanish and English (texts published in both Spanish and English) and multilingual (texts published in a variety of languages with no preference).

Table 5. Language of articles and subject areas 


\begin{tabular}{|c|c|c|c|c|c|c|c|c|c|c|c|c|c|c|}
\hline \multirow[b]{2}{*}{ Subject } & \multicolumn{2}{|c|}{ Spanish } & \multicolumn{2}{|c|}{ English } & \multicolumn{2}{|c|}{ Catalan } & \multicolumn{2}{|c|}{ Italian } & \multicolumn{2}{|c|}{$\begin{array}{l}\text { Spanish } \\
\text { and } \\
\text { English }\end{array}$} & \multicolumn{2}{|c|}{ Multilingual } & \multicolumn{2}{|c|}{ TOTAL } \\
\hline & No & $\%$ & No & $\%$ & No & $\%$ & No & $\%$ & No & $\%$ & No & $\%$ & No & $\%$ \\
\hline $\begin{array}{l}\text { Arts and } \\
\text { humanities }\end{array}$ & 39 & $55.7 \%$ & 5 & $7.1 \%$ & 0 & $0.0 \%$ & 1 & $1.4 \%$ & 10 & $14.3 \%$ & 15 & $21.4 \%$ & 70 & $17.2 \%$ \\
\hline $\begin{array}{l}\text { Health } \\
\text { sciences }\end{array}$ & 84 & $62.2 \%$ & 17 & $12.6 \%$ & 1 & $0.7 \%$ & 0 & $0.0 \%$ & 28 & $20.7 \%$ & 5 & $3.7 \%$ & 135 & $33.3 \%$ \\
\hline Life sciences & 4 & $16.7 \%$ & 8 & $33.3 \%$ & 1 & $4.2 \%$ & 0 & $0.0 \%$ & 7 & $29.2 \%$ & 4 & $16.7 \%$ & 24 & $5.9 \%$ \\
\hline $\begin{array}{l}\text { Experimental } \\
\text { sciences }\end{array}$ & 4 & $30.8 \%$ & 5 & $38.5 \%$ & 0 & $0.0 \%$ & 0 & $0.0 \%$ & 3 & $23.1 \%$ & 1 & $7.7 \%$ & 13 & $3.2 \%$ \\
\hline Social sciences & 70 & $53.0 \%$ & 7 & $5.3 \%$ & 3 & $2.3 \%$ & 0 & $0.0 \%$ & 40 & $30.3 \%$ & 12 & $9.1 \%$ & 132 & $32.5 \%$ \\
\hline Engineering & 10 & $50.0 \%$ & 7 & $35.0 \%$ & 0 & $0.0 \%$ & 0 & $0.0 \%$ & 2 & $10.0 \%$ & 1 & $5.0 \%$ & 20 & $4.9 \%$ \\
\hline $\begin{array}{l}\text { Mathematics } \\
\text { and physics }\end{array}$ & 0 & $0.0 \%$ & 11 & $91.7 \%$ & 0 & $0.0 \%$ & 0 & $0.0 \%$ & 1 & $8.3 \%$ & 0 & $0.0 \%$ & 12 & $3.0 \%$ \\
\hline Total & 211 & $52.0 \%$ & 60 & $14.8 \%$ & 5 & $1.2 \%$ & 1 & $0.2 \%$ & 91 & $22.4 \%$ & 38 & 9.4\% & 406 & $100.0 \%$ \\
\hline
\end{tabular}

The overall distribution by language fits perfectly with the characteristics of the peripheral countries of scientific communication. Spanish was the majority language, appearing in three-quarters of the journals (52\% only in Spanish and 22\% in Spanish and English). English was used in 37\% of the journals (15\% only in English and 22\% in Spanish and English), a finding that is in line with the progressive internationalization of Spanish journals. Finally, publications in Catalan only accounted for $1 \%$ of the total.

As for the distribution by subject areas, mathematics and physics journals were all published in English (92\% only English and 8\% in English and Spanish) and none only in Spanish. The majority of journals were published in English or in English and Spanish in the experimental sciences (38.5\% and $23.1 \%$, respectively) and life sciences (33.3\% and $29.3 \%$, respectively). In the rest of the subject areas Spanish was largely predominant.

Another aspect of some relevance is the publication of full versions in more than one language (not shown in the table). At the time of the study, 12 journals (3\% of the total) had full versions in Spanish and English, and 3 more journals were published in two languages simultaneously (one in Catalan and Spanish, one in Catalan and English, and one in Galician and Spanish).

\subsection{Presence in web portals}


Journal portals aggregate journals and allow them to reach a defined audience or community, so they improve their dissemination and visibility. The vast majority of portals are managed by institutions related to universities or research institutes such as the CSIC, Dialnet and the Spanish Foundation for Science and Technology (FECYT). They include eRevistas, with 127 journal titles, and eDialnet, with 46. There are only two commercial platforms in the table: Elsevier, second with 70 titles, and Springer, with 12.

Table 6. Journal portals

\begin{tabular}{llrr} 
Portal & Institution & Journals & $\%$ \\
\hline e-Revist@s & MINECO, CSIC & 127 & $31.3 \%$ \\
Elsevier Journals and Science Direct & Elsevier & 70 & $17.2 \%$ \\
eDialnet & Dialnet Foundation & 46 & $11.3 \%$ \\
RECYT & FECYT & 39 & $9.6 \%$ \\
RACO & CBUC, BC, GenCat & 36 & $8.9 \%$ \\
CSIC Scientific Journals & CSIC & 32 & $7.9 \%$ \\
Complutense Scientific Journals & Universidad Complutense de Madrid & 28 & $6.9 \%$ \\
SciELO Spain & SciELO & 20 & $4.9 \%$ \\
SpringerLink & Springer & 12 & $3.0 \%$ \\
RCUB & Universitat de Barcelona & 11 & $2,7 \%$ \\
Scientific Journals & Universidad de Murcia & 8 & $2.0 \%$ \\
Scientific Journals & Universidad de Navarra & 8 & $2.0 \%$ \\
ReDi & Universitat Autònoma de Barcelona & 7 & $1.7 \%$
\end{tabular}

(Abbreviations: BC, Library of Catalonia; CBUC, Consortium of Academic Libraries of Catalonia; CSIC, Spanish National Research Council; FECYT, Spanish Foundation for Science and Technology)

In general, the portals provide access to journals from an alphabetical list and by subject area, and offer the full texts of the articles. However, the full texts of the journals are not always available directly. Sometimes the portals redirect users to other portals or only contain the references. No Spanish portal has played a key role in disseminating and improving the scientific quality of journals as SciELO has done in Brazil20.

\subsection{Type of access}

The following types of access define the conditions under which a user can view the contents of the journals ${ }^{21}$ :

- Gratis: immediate online access to content at no cost to the user.

- Gratis electronic version and subscription-paid print version. 
- Gratis after an embargo: the content can be accessed after a period of time, usually between 3 and 12 months. This option is used by subscription journals that want to reach a wider audience.

- Hybrid: subscription journals in which articles are open access when the authors pay an APC; otherwise access is subject to payment.

- Restricted to subscribers: access to all versions of the journal is limited to subscribers.

As shown in Table 7, almost $60 \%$ of the journals are available without cost and immediately (54.2\% free plus $5.2 \%$ with free electronic versions). If we add the journals that are free after an embargo period (15.3\%), the total is $75 \%$. Subscriptionpaid journals also include hybrid ones that apply APCs—only 14 titles, 9 of which are published by Springer.

Among the publishers the vast majority of universities and research centers (78\%) offer gratis dissemination of their contents. Restricted access to subscribers is logically concentrated in commercial publishers, although it is noteworthy that $31 \%$ of commercial journals allow their online contents to be viewed free of charge and, if those imposing an embargo are included, the figure reaches $45 \%$. This is explained by the fact that many of these journals belong to scientific associations that have production and distribution agreements with commercial publishers and offer the articles in open access online (e.g. some Elsevier journals in the area of Health Sciences). 
Table 7. Type of access by subject area and type of publisher

\begin{tabular}{|c|c|c|c|c|c|c|c|c|c|c|}
\hline \multirow[b]{2}{*}{$\begin{array}{l}\text { Type of } \\
\text { publisher }\end{array}$} & \multicolumn{2}{|c|}{ Gratis } & \multicolumn{2}{|c|}{$\begin{array}{c}\text { Gratis } \\
\text { electronic } \\
\text { version and } \\
\text { paid print } \\
\text { version }\end{array}$} & \multicolumn{2}{|c|}{$\begin{array}{l}\text { Gratis+ } \\
\text { embargo }\end{array}$} & \multicolumn{2}{|c|}{$\begin{array}{l}\text { Restricted to } \\
\text { subscribers }\end{array}$} & \multicolumn{2}{|c|}{ Total } \\
\hline & $\mathbf{n}$ & $\%$ & $\mathbf{n}$ & $\%$ & $\mathbf{n}$ & $\%$ & $\mathbf{n}$ & $\%$ & $\mathbf{n}$ & $\%$ \\
\hline Private non-profit & 54 & $59.3 \%$ & 1 & $1.1 \%$ & 13 & $14.3 \%$ & 23 & $25.3 \%$ & 91 & $22.4 \%$ \\
\hline Government & 12 & $60.0 \%$ & 0 & $0.0 \%$ & 5 & $25.0 \%$ & 3 & $15.0 \%$ & 20 & $4.9 \%$ \\
\hline Commercial & 21 & $16.7 \%$ & 19 & $15.1 \%$ & 16 & $12.7 \%$ & 70 & $55.6 \%$ & 126 & $31.0 \%$ \\
\hline Academic & 133 & $78.7 \%$ & 1 & $0.6 \%$ & 28 & $16.6 \%$ & 7 & $4.1 \%$ & 169 & $41.6 \%$ \\
\hline Subject area & 220 & $54.2 \%$ & 21 & $5.2 \%$ & 62 & $15.3 \%$ & 103 & $25.4 \%$ & 406 & $100.0 \%$ \\
\hline $\begin{array}{l}\text { Arts and } \\
\text { Humanities }\end{array}$ & & $62.9 \%$ & 0 & $0.0 \%$ & 15 & $21.4 \%$ & 11 & $15.7 \%$ & 70 & $17.2 \%$ \\
\hline Health Sciences & 48 & $35.6 \%$ & 17 & $12.6 \%$ & 15 & $11.1 \%$ & 55 & $40.7 \%$ & 135 & $33.3 \%$ \\
\hline Life Sciences & 19 & $79.2 \%$ & 0 & $0.0 \%$ & 1 & $4.2 \%$ & 4 & $16.7 \%$ & 24 & $5.9 \%$ \\
\hline Social Sciences & 84 & $63.6 \%$ & 3 & $2.3 \%$ & 27 & $20.5 \%$ & 18 & $13.6 \%$ & 132 & $32.5 \%$ \\
\hline $\begin{array}{l}\text { Experimental } \\
\text { Sciences }\end{array}$ & 10 & $76.9 \%$ & 0 & $0.0 \%$ & 1 & $7.7 \%$ & 2 & $15.4 \%$ & 13 & $3.2 \%$ \\
\hline Engineering & 12 & $60.0 \%$ & 1 & $5.0 \%$ & 2 & $10.0 \%$ & 5 & $25.0 \%$ & 20 & $4.9 \%$ \\
\hline $\begin{array}{l}\text { Mathematics and } \\
\text { Physics }\end{array}$ & 3 & $25.0 \%$ & 0 & $0.0 \%$ & 1 & $8.3 \%$ & 8 & $66.7 \%$ & 12 & $3.0 \%$ \\
\hline Total & 220 & $54.2 \%$ & 21 & $5.2 \%$ & 62 & $15.3 \%$ & 103 & $25.4 \%$ & 406 & $100.0 \%$ \\
\hline
\end{tabular}

The subject areas that are most offered in open access are life sciences and experimental sciences (79\% and $77 \%$, respectively). On the other hand, the subject areas that most charge subscriptions are mathematics and physics (66.7\%) and health sciences $(40.7 \%)$, corresponding to the fact that they are the areas with the highest coverage by commercial publishers.

\subsection{Permission for self-archiving}


This section analyses the publishing policies of journals with regard to granting permission for self-archiving in open access repositories and the versions in which this can be done. The journals are given a color according to whether self-archiving is permitted and the type of version, following Sherpa/Romeo ${ }^{22}$ :

- White: self-archiving is not permitted

- Yellow: self-archiving of the pre-print version of the article (the version submitted before peer review) is permitted.

- Blue: self-archiving of the post-print version of the article (the author or publisher version) is permitted.

- Green: self-archiving of both pre- and post-print versions is permitted.

Since self-archiving permission is not always explicitly mentioned in the description of the journals, this information was collected directly from the publishers or inferred from the publishing licenses.

Only $9 \%$ of the journals analyzed make no explicit mention of copyright. The journals published by commercial publishers in the areas of health and mathematics are those with the highest percentage of references to copyright, because the contracts with publishers (mostly Elsevier and Springer) are standardized.

Table 8. ROMEO color according to type of publisher and subject area

\begin{tabular}{|c|c|c|c|c|c|c|c|c|c|c|c|}
\hline & \multicolumn{8}{|c|}{ Color } & & & \multirow{3}{*}{$\begin{array}{l}\% \text { of self- } \\
\text { archiving }\end{array}$} \\
\hline & \multicolumn{2}{|c|}{ Green } & \multicolumn{2}{|c|}{ Blue } & \multicolumn{2}{|c|}{ White } & \multicolumn{2}{|c|}{ Unassigned } & \multicolumn{2}{|c|}{ Total } & \\
\hline & $\mathbf{n}$ & $\%$ & $\mathbf{n}$ & $\%$ & $\mathbf{n}$ & $\%$ & $\mathbf{n}$ & $\%$ & $\mathbf{n}$ & $\%$ & \\
\hline Private non-profit & 9 & $9.9 \%$ & 48 & $52.7 \%$ & 20 & $22.0 \%$ & 14 & $15.4 \%$ & 91 & $22.4 \%$ & $62.6 \%$ \\
\hline Government & 0 & $0.0 \%$ & 11 & $55.0 \%$ & 6 & $30.0 \%$ & 3 & $15.0 \%$ & 20 & $4.9 \%$ & $55.0 \%$ \\
\hline Commercial & 81 & $64.3 \%$ & 12 & $9.5 \%$ & 25 & $19.8 \%$ & 8 & $6.3 \%$ & 126 & $31.0 \%$ & $73.0 \%$ \\
\hline Academic & 20 & $11.8 \%$ & 130 & $76.9 \%$ & 5 & $3.0 \%$ & 14 & $8.3 \%$ & 169 & $41.6 \%$ & $88.8 \%$ \\
\hline $\begin{array}{l}\text { Total } \\
\text { Subject area }\end{array}$ & 110 & $27.1 \%$ & 201 & $49.5 \%$ & 56 & $13.8 \%$ & 39 & $9.6 \%$ & 406 & $100.0 \%$ & \\
\hline $\begin{array}{l}\text { Arts and } \\
\text { Humanities }\end{array}$ & & $8.6 \%$ & 47 & $67.1 \%$ & 2 & $2.9 \%$ & 15 & $21.4 \%$ & 70 & $17.2 \%$ & $75.7 \%$ \\
\hline Health Sciences & 67 & $49.6 \%$ & 27 & $20.0 \%$ & 31 & $23.0 \%$ & 10 & $7.4 \%$ & 135 & $33.3 \%$ & $69.6 \%$ \\
\hline Life Sciences & 0 & $0.0 \%$ & 18 & $75.0 \%$ & 3 & $12.5 \%$ & 3 & $12.5 \%$ & 24 & $5.9 \%$ & $75.0 \%$ \\
\hline $\begin{array}{l}\text { Experimental } \\
\text { Sciences }\end{array}$ & 2 & $15.4 \%$ & 10 & $76.9 \%$ & 0 & $0.0 \%$ & 1 & $7.7 \%$ & 13 & $3.2 \%$ & $92.3 \%$ \\
\hline
\end{tabular}




\begin{tabular}{l|rr|rr|rr|rr|rr|r|} 
Social Sciences & 25 & $18.9 \%$ & 80 & $60.6 \%$ & 19 & $14.4 \%$ & 8 & $6.1 \%$ & 132 & $32.5 \%$ & $79.5 \%$ \\
Engineering & 3 & $15.0 \%$ & 15 & $75.0 \%$ & 0 & $0.0 \%$ & 2 & $10.0 \%$ & 20 & $4.9 \%$ & $85.0 \%$ \\
$\begin{array}{l}\text { Mathematics and } \\
\text { Physics Total }\end{array}$ & $\mathbf{1 1 0}$ & $\mathbf{5 8 . 3 \%}$ & $\mathbf{2 7 . 1 \%}$ & $\mathbf{3 3 . 3 \%}$ & $\mathbf{2 0 1}$ & $\mathbf{4 0 . 3 \%}$ & 0 & $0.0 \%$ & 12 & $3.0 \%$ & $91.7 \%$ \\
& & $\mathbf{5 6}$ & $\mathbf{1 3 . 8 \%}$ & $\mathbf{3 9}$ & $\mathbf{9 . 6 \%}$ & $\mathbf{4 0 6}$ & $\mathbf{1 0 0 . 0 \%}$ &
\end{tabular}

Analysis of permission for self-archiving of articles shows that $76 \%$ of the journals (green and blue) at least grant permission for archiving the post-print version of the article in an open access repository. Among the green journals the health sciences are dominant because most of them are published by Elsevier, which allows selfarchiving of pre-and post-print author versions dependent on the open access policy of the institution. Blue journals are mostly published by government agencies or professional associations and, in this case, the published version can be selfarchived. The journals published by universities and research centers are the most open ones in granting this permission

Creative Commons licenses are used by 99 journals (24\%), of which 76 are published by universities and research centers.

\section{Open access}

The open access model is the one most noticeably impacting the functioning of scholarly journals and marking their publishing strategy. These changes are occurring both in journals published by public entities, which have easily made the transition from subscription to open access, and in journals of commercial publishers offering the possibility of releasing articles for self-archiving on payment of APCs.

How can one determine whether a scholarly journal is open access? According to the definition of open access ${ }^{23}$, a scientific journal complies with the principles of open access when it provides gratis access to its content and the copyright holder allows re-use of the texts for responsible purposes. The definition is clear but the reality is sometimes difficult to determine owing to lack of information about the journals' publishing policy. There is a wide range of "openness" of journals in terms of access and copyright. In fully open access journals the content is gratis from the time of publication and the articles are distributed under licenses that only require recognition of authorship.

In our case we required the presence of both conditions (gratis and free of some rights) in order to consider that a journal was open access. As shown in Table 9, a 
total of 197 journals (48\%) were both gratis and permitted self-archiving (blue or green). This is the reference value. If we compare this figure with the data on open access provided by Ulrich's directory, we find that only 133 journals (32.7\%) in our study are considered open access, a substantially lower percentage. This result is explained by the difficulty of determining whether a journal is open access.

Only 69 of the 197 journals appeared in the DOAJ directory (December 2013), a finding which contrasts with data from India, which has the majority of its open access journals registered in this directory ${ }^{24}$.

Table 9. Type of access and permission for self-archiving

\begin{tabular}{|c|c|c|c|c|c|c|c|c|c|}
\hline \multirow[b]{3}{*}{ Type of access } & \multicolumn{8}{|c|}{ Color } & \multirow{3}{*}{ Total } \\
\hline & \multicolumn{2}{|c|}{ Green } & \multicolumn{2}{|c|}{ Blue } & \multicolumn{2}{|c|}{ White } & \multicolumn{2}{|c|}{$\begin{array}{c}\text { Unassigne } \\
d\end{array}$} & \\
\hline & $\mathbf{n}$ & $\%$ & $\mathbf{n}$ & $\%$ & $\mathbf{n}$ & $\%$ & $\mathbf{n}$ & $\%$ & \\
\hline Gratis & 21 & $10 \%$ & 156 & $71 \%$ & 23 & $11 \%$ & 20 & $9 \%$ & 220 \\
\hline $\begin{array}{l}\text { Gratis electronic } \\
\text { version and paid } \\
\text { print version }\end{array}$ & 17 & $81 \%$ & 3 & $14 \%$ & 1 & $5 \%$ & 0 & $0 \%$ & 21 \\
\hline Gratis+ embargo & 18 & $29 \%$ & 28 & $45 \%$ & 12 & $19 \%$ & 4 & $7 \%$ & 62 \\
\hline Restricted to & 54 & $52 \%$ & 14 & $14 \%$ & 20 & $19 \%$ & 15 & $15 \%$ & 103 \\
\hline Total & 110 & & 201 & & 56 & & 39 & & 406 \\
\hline
\end{tabular}

It must also be noted that 44 gratis journals (20\% of the total) do not grant permission for self-archiving ("White") or do not state so ("Unassigned"). Perhaps in many cases there is a lack of knowledge on these issues.

Finally, a group of 46 journals ( $11 \%$ of the total) that are gratis after an embargo and grant permission for self-archiving ("Green" or "Blue") can be considered to have the second level of openness, after the group of 197 open access titles.

There are various models of open access between countries and geographical areas. At one extreme are countries in which the APC system is predominant. This is the case in the USA, Great Britain and the Netherlands, with a large presence of commercial publishers, and also in India, where publishers have specialized in this type of operation ${ }^{25}$. According to DOAJ, $64 \%$ of the journals in Great Britain and 50\% of those in India apply APCs. In Spain and Brazil, the figures are $4 \%$ and 5\%, 
respectively. At the other extreme is Brazil, where there is a residual commercial presence and $97 \%$ of the journal titles in $\mathrm{WoS}^{26}$ are open access without author payment of APCs because public funding is available. The situation of Spain, with $48 \%$ of journals open access and a negligible presence of APCs, is closer to the Brazilian model but still some distance behind.

\section{Conclusions}

Spanish journals have increased their presence in impact indexes in recent years, especially in the period 2005-2010, when the number of journals in JCR doubled. If we take as the reference the data of the study by Bordons ${ }^{27}$ the figure has risen from 31 journals in the JCR to our finding of 171 in WoS and 406 in WoS and Scopus combined. These figures represent about $20 \%$ of all Spanish scholarly journals.

It has also been shown that to obtain a detailed picture of the evolution of the sector it is not sufficient to use data from journal directories, which contain inaccuracies and are not updated with sufficient frequency. Although it is a long and laborious process, it is essential to collect information directly from the journals in order to obtain reliable data.

The majority of Spanish journals (63\% of the total) have appeared since 1980. In subject area, the health sciences (33\%) and social sciences (32\%) are now predominant, whereas in 2002 medicine (60\%) was predominant. Universities and research centers are the major publishers, with $41 \%$ of the total, followed by commercial publishers with $31 \%$ (but $73 \%$ in health Sciences). This represents a slight change to the situation in 2002 , when commercial publishers accounted for $40 \%$ of the total (60\% in health sciences).

Spanish is the majority language (52\% of journals) and English still has a low presence ( $15 \%$ of journals), although it is noteworthy that $22 \%$ of the journals publish texts in both languages and that in some subject areas (mathematics and physics, experimental sciences and life sciences) English is the majority language. These ratios are expected to increase as part of the necessary process of internationalization of journals.

Several journal portals, some with a large number of titles (e.g. eRevistas), are contributing to the dissemination of the journals but they do not play such a prominent role in promotion and development as SciELO has done in Brazil. 
Of the journals, $60 \%$ are gratis immediately after publication and $76 \%$ grant permission to self-archive a version of the manuscript. By crossing both figures, we estimate that $48 \%$ of all journals are open access (gratis and permission for selfarchiving). This figure differs from those of Ulrich's directory and the DOAJ directory (which, respectively, consider only $33 \%$ and $30 \%$ of the journals in our study to be open access), supporting our decision to collect this information directly from the journals. Furthermore, there is a need to clarify the conditions that must be met to define a journal as open access.

Given our interest in continuing to collect data on journals, future studies will closely follow the evolution of the sector in response to the two major challenges that are currently affecting it: internationalization and the impact of open access on the business model. The evidence can also be used to promote the inclusion of references to rights as a quality criterion in the evaluation of journals.

Ernest Abadal is a professor of the Faculty of Library and Information Science at University of Barcelona, Catalonia, Spain. Co-coordinator of "Open Access to science in Spain" research group (http://www.accesoabierto.net). Personal webpage: http://bd.ub.es/pub/abadal.

Rosângela Schwarz Rodrigues is a professor of the Graduate Program of Information Science at Federal University of Santa Catarina, Brazil. Publications and curriculum at http://buscatextual.cnpq.br/buscatextual/visualizacv.do?id=K4763757P9.

Remedios Melero is a researcher at the Agrochemistry and Food Technology Institute of the Spanish National Research Council. Co-coordinator of "Open Access to science in Spain" research group (http://www.accesoabierto.net), and partner of FOSTER (Facilitate Open Science Training for European Research), a project funded by the EC under the 7FP.

Miguel Navas-Fernández is a librarian at the Special Libraries of the Catalonia Government (on leave), and $\mathrm{PhD}$ researcher at the Faculty of Library and Information Science at University of Barcelona. Member "Open Access to science in Spain" research group ((http://www.accesoabierto.net). Webpage at ORCID: http://orcid.org/0000-0002-5191-238X

\section{References}

1. A. N. Greco (ed.), Scholarly publishing in emerging nations [The Essential Journal of Scholarly Publishing: volume 2] (University of Toronto Press, 2012) http://dx.doi.org/10.3138/ejsp.vol2

2. T. Hedlund, I. Rabow, 'Scholarly publishing and open access in the Nordic countries,' Learned Publishing, 22, 3 (2009): 177-186.

http://dx.doi.org/10.1087/2009303 
3. I. Hebrang Grgić, 'Scholarly journals at the periphery: the case of Croatia,' Learned Publishing, 27, 1 (2014): 15-20. http://dx.doi.org/10.1087/20140103

4. A. L. Packer, 'Os periódicos brasileiros e a comunicação da pesquisa nacional,' Rev. USP 89 (2011): 26-61, http://rusp.scielo.br/scielo.php?script=sci arttext\&pid=S010399892011000200004\&lng=pt\&nrm=iso

5. R. S. Rodrigues, E. Abadal, 'Scientific journals in Brazil and Spain: alternative publish models,' Journal of the American Society for Information Science and Technology (2014). http://dx.doi.org/10.1002/asi.23115

6. A. Sánchez Hernández, V. Soria, M.G. Landa, V. Soria, 'Calidad y excelencia editorial de las revistas científicas mexicanas ante nuevos retos,' IBERSID: Avances y perspectivas de sistemas de información y documentación, 1 (2008): 93-108.

7. H. Xiao-Jun, C.Zhen-Ying, S.Hui-Yun, 'Chinese scientific journals: how they can survive,' Learned Publishing, 25, 3 (2012): 219-224.

http://dx.doi.org/10.1087/20120309

8. D. Hu, 'The availability of open access journals in the humanities and social sciences in China,' Journal of Information Science, 38, 1 (2012): 64-75. http://jis.sagepub.com/cgi/doi/10.1177/0165551511428919

9 Y.Y. Sun, M. Mao, 'The current status of the publishing industry in China,' Scholarly Publishing in Emerging Nations, 2 (2012): 108-118. https://muse.jhu.edu/login?auth=0\&type=summary\&url=/journals/journal of schola rly publishing/v041/41.1.sun.pdf

10. B. Mukherjee, 'Green and gold open access in India'. Learned Publishing, 27, 1 (2014): 21-32. http://dx.doi.org/10.1087/20140104

11. C. Urdín, 'La edición de revistas científicas en España'. La edición de revistas científicas: guía de buenos usos (Madrid: Cindoc, 2001): 11-16.

http://hdl.handle.net/10261/4347

12. M. Bordons, A. Felipe, I. Gómez, 'Revistas científicas españolas con factor de impacto en el año 2000,' Revista Española de Documentación Científica, 1, 25 (2002): 49-71. http://digital.csic.es/bitstream/10261/11560/1/147.pdf

13. J. Osca-Lluch, J. Haba, O. Mínguez, G. Navarro, E. Velasco, L. Salom, 'Difusión y factor de impacto nacional e internacional de las revistas científicas españolas,' Anales de Documentación, 11 (2008): 145-164.

http://revistas.um.es/analesdoc/article/view/24861 
14. E. Abadal, L. Rius, 'Revistas científicas de las universidades españolas: acciones básicas para aumentar su difusión e impacto,' Revista Española de Documentación Científica, 31, 2 (2008): 242-262.

http://eprints.rclis.org/handle/10760/11539

15. L. Rodríguez-Yunta, E. Giménez-Toledo, 'Fusión, coedición o reestructuración de revistas científicas en humanidades y ciencias sociales,' El Profesional de la Información, 22, 1 (Jan./Feb2013): 36-45.

http://dx.doi.org/10.3145/epi.2013.ene.05

16. J. Testa, The globalization of Web of Science: 2005-2010, (2011): 26. http://wokinfo.com/media/pdf/globalwos-essay.pdf

17. M. Bordons, A. Felipe, I. Gómez, 'Revistas científicas españolas con factor de impacto en el año 2000,' Revista Española de Documentación Científica, 1, 25 (2002): 49-71. http://digital.csic.es/bitstream/10261/11560/1/147.pdf

18. M. Bordons, A. Felipe, I. Gómez, 'Revistas científicas españolas con factor de impacto en el año 2000,' Revista Española de Documentación Científica, 1, 25 (2002): 49-71. http://digital.csic.es/bitstream/10261/11560/1/147.pdf

19. E. Giménez-Toledo, 'Revistas científicas en 2012: trilogía para la reflexión y la acción,'ThinkEPI (2012). http://www. thinkepi.net/revistas-cientificas-2012-trilogiareflexion-accion

20. A. L. Packer, 'Os periódicos brasileiros e a comunicação da pesquisa nacional,' Rev. USP 89 (2011): 26-61, http://rusp.scielo.br/scielo.php?script=sci arttext\&pid=S0103-

99892011000200004\&lng=pt\&nrm=iso

21. R. Melero, F. Abad, 'Revistas open access: características, modelos económicos y tendencias,' BiD: textos universitaris de biblioteconomia $i$ documentació, 20 (2008). http://bid.ub.edu/20meler2.htm

22. Sherpa/Romeo. 'Definitions and terms', (2006-2014). http://www.sherpa.ac.uk/romeo/definitions.php?la=en\&flDnum=|\&mode=simple\&ve rsion=\#colours

23. Budapest Open Access Initiative (Budapest, 2012). http://www.soros.org/openaccess/read.shtml

24. B. Mukherjee, 'Green and gold open access in India'. Learned Publishing, 27, 1 (2014): 21-32. http://dx.doi.org/10.1087/20140104

25. B. Mukherjee, 'Green and gold open access in India'. Learned Publishing, 27, 1 (2014): 21-32. http://dx.doi.org/10.1087/20140104 
26. R. S. Rodrigues, E. Abadal, 'Scientific journals in Brazil and Spain: alternative publish models,' Journal of the American Society for Information Science and Technology (2014). http://dx.doi.org/10.1002/asi.23115

27. M. Bordons, A. Felipe, I. Gómez, 'Revistas científicas españolas con factor de impacto en el año 2000,' Revista Española de Documentación Científica, 1, 25 (2002): 49-71. http://digital.csic.es/bitstream/10261/11560/1/147.pdf 